\title{
INCENTIVES AND MOTIVATION EFFECT ON THE PERFORMANCE OF EMPLOYEES IN PART STEVEDORE PT. RMK ENERGY PALEMBANG
}

\author{
M. Fatli LA, Zunaidah and Bemby \\ Master of Management, University of Sriwijaya Palembang, Indonesia \\ Srijaya road, Bukit Besar, Bukit Lama, Ilir Barat I, Palembang, South Sumatra 30128
}

http://doi.org/10.35409/IJBMER.2019.2407

\begin{abstract}
This research is used to determine how much influence the variable incentive and motivation of the employees working at the unloading PT.RMK-E Palembang. The population in this study were all employees of unloading PT. RMK-E Palembang, amounting to 68 people. Sources of data in this study using primary data obtained through questionnaires closed while the technique of data analysis using multiple linear regression analysis. These results indicate that incentives have a positive and significant impact on the performance of employees in the unloading PT.RMK- E Palembang, motivation positive and significant effect on the performance of employees in the unloading PT. RMK-E Palembang, insnetif and with the same motivation berpangruh positive and significant impact on the performance of employees in the unloading PT.RMK-E Palembang and motivation become the most dominant variable affecting the performance of employees in the unloading PT.RMK-E Palembang. It is expected that through this research can be a matter of evaluation for the company and employees unloading PT.RMKE Palembang to achieve effective motivation and good incentives so that the achievement of stability and harmony of the company.
\end{abstract}

Keyword: Incentives, Motivation, Employee Performance.

\section{INTRODUCTION}

Rivai (2015) incentives are payments relating to the performance and gainsharing, Namely the employee profit sharing due to the increase in labor productivity or cost savings. In addition to incentives, a company in the following all developments require a motivation so that employees are able to work well. According to Robbins (2014) motivation is a process which contributes to the intensity, direction, and duration of the ongoing efforts towards the achievement of individual targets. The results are intended to be productivity, presence or perialu other creative work. According Mangkunagara (2015) is the result of performance seen by the quality and quantity of an employee in performing their duties and responsibilities in accordance with the existing workload.

One company that is currently developing in Palembang engaged in mining, especially coal, PT. Mulia Kencana Energy chain (PT. RMK-E) is one of the RMK group. In 2010, realizing that the South Sumatra has the largest coal reserves in Indonesia. The company has focused its operations in Palembang, South Sumatra. With abundant reserves, the development of 
Vol. 2, No. 04; 2019

ISSN: 2581-4664

infrastructure is the final step necessary to ensure a constant delivery. Therefore, the logistics opportunities are very large and there is confidence in this region as developed transportation.

Currently, PT. RMK-E already has two compayer and building the new one compayer used to move coal from the stockpile at the port to barge through the loading and unloading of ships. The ship unloading cargo handling all compayer of line 1, line 2 and line 3 in which each line has employees with their respective duties. Number of employees unloading at. RMK-E Palembang in 2018 of 68 people consisting of operational staff of 30 people, master of loading as many as 8 people, and porters, as many as 30 people. In practice stevedoring company PT RMK-E apply incentive policies to all employees. It is hoped that the provision of incentives to improve the performance of employees in order to support efforts to achieve the goal.

In this study, workers unloading PT.RMK-E Palembang motivation is influenced by the type of material incentives that pushed semngat work with incentives in the form of the number of values. The data in the employee incentive PT.RMK-E Palembang at the unloading as follows.

Table 1 Data Incentives PT. RMK-E Palembang In 2018

\begin{tabular}{|llll|}
\hline categories & Total Value & Frequency & Percentage (\%) \\
\hline High & $>$ Rp. 1,000,000 & 0 & 0 \\
moderate & Rp 500,000 - Rp 1,000,000 & 13 & 19.1 \\
Low & $<$ Rp 250,000 & 55 & 80.9 \\
\hline & total & 68 & 100 \\
\hline
\end{tabular}

source: stevedoring company PT. RMK- E Palembang, 2018.

Based on Table 1, no employees unloading PT.RMK-E were included in the high category. Incentives received by employees in a category is as many as 13 people or $19.1 \%$, while 55 employees or $80.9 \%$ were in the low category is <IDR. 250,000. Number of employees received incentive bonuses are included with each month as measured by the achievement of the targets every month. Increasingly achievement exceeds the target then the incentive is also higher, with yields of > Rp.1000.000. Based on table 1.2, as many as 55 people who earn lower incentive not achieve employment targets allegedly due to poor employee performance. Setting the amount of incentives for employees are fully determined by the unloading PT.RMK-E Palembang.

One role of human resources in a company so that employees want to work and use skills or his ability to the fullest. When the employee's performance is low, will affect the timing of completion of loading and unloading ships. Based on data obtained from PT. RMK-E Palembang, unloading REMEDY results in 2018 are as follows.

Table 1.2 Data Loading and Unloading Ships PT. RMK-E Palembang Last 6 Months

\begin{tabular}{|c|c|c|c|c|}
\hline NO & Month & $\begin{array}{l}\text { Target Ship } \\
\text { Unloading }\end{array}$ & $\begin{array}{l}\text { Ship } \\
\text { Unloading } \\
\text { Achieveme } \\
\text { nt }\end{array}$ & $\begin{array}{l}\text { Number of } \\
\text { Employees } \\
\text { Unloading ship }\end{array}$ \\
\hline 1 & July & 60 & 50 & 68 \\
\hline 2 & August & 60 & 51 & 68 \\
\hline
\end{tabular}




\section{International Journal of Business Management and Economic Review}

Vol. 2, No. 04; 2019

ISSN: 2581-4664

\begin{tabular}{|lllll|}
\hline \hline 3 & September & 60 & 42 & 68 \\
4 & October & 60 & 63 & 68 \\
5 & November & 60 & 65 & 68 \\
6 & December & 60 & 54 & 68 \\
\hline
\end{tabular}

source:Stevedoring company PT. RMK- E Palembang, 2018.

Based on Table 1.2 it can be seen the number of completion of unloading ships per month for six months. Based on these data are still many activities that do not meet the targets included the months of July, August, September, and December of below 60 ships. The lack of achievement is probably because of working hours when the ship entered the harbor erratic so employees per shift must guard by the number of excessive working hours and occupational safety level is still low.Based on the above presentation, the researchers are interested to analyze the relationships these three variables with title "INFLUENCE OF INCENTIVES AND MOTIVATION TO PERFORMANCE OF EMPLOYEES IN PART STEVEDORE PT. RMK ENERGY Palembang. "

\section{FORMULATION OF THE PROBLEM}

a. How does the influence of motivation on employee performance stevedoring company PT. RMKE Palembang?.

b. How the incentive effect on employee performance stevedoring company PT. RMK-E?.

c. How to influence the motivation and incentive to employees performance stevedoring company PT. RMK-E?.

\section{THEORITICAL REVIEW}

\section{Incentive}

According Hasibuan (2013) suggested that additional remuneration incentives are granted to employees of the achievements of more than standard. This incentive is a tool that is in use supporting the principle of a fair in granting compensation or in other words encouragement to someone so willing to work with through the willingness and motivation of employees to the creation of quality performance and achievement of company objectives.

Siagian (2010), the type - the type of incentives are: a. Piece work b.Bonus c. Commission d. Incentives for eksekutife. Maturity curve

While the type - the type of Incentives According Sarwoto in Suwatno and Priansa (2011: 235-236), there are two kinds of incentives can be given to employees, namely:

- Material incentives: bonus, commission, profit sharing, deferred compensation.

Motivation

- Non-material incentives

Samsudin (2006) describes a condition or energy motivation that drives self-directed or directed employees to achieve organizational goals of the company. So, motivation is a condition that causes a boost or to evoke the spirit of an employee to achieve its goals.

Abraham Maslow's Motivation Theory quoted in Hasibuan (2013) argued that the hierarchy of human needs are as follows:

- Physical needs

- Need for security

- social needs

- The need for self-esteem or appreciation 


\section{International Journal of Business Management and Economic Review}

Vol. 2, No. 04; 2019

ISSN: $2581-4664$

\section{Performance}

Sianipar (2004) that the performance of the work ability of some person or group of people to a particular job at a time. The final results obtained on the performance of employees may be goods and services, actions or behaviors, compensation skills, and increase specific skills relevant to the objectives of the company.

According to Gomes (2005), there are several criteria that can be used to assess and measure the performance of each employee based on the description each employee, namely: 1 . The quantity of work, 2. Quality of work 3. Job knowledge (knowledge work), 4. creativeness (creativity) 5. cooperation (cooperation), 6. Dependability (consciousness), 7. initiative (initiative), 8. personal qualities (personal qualities).

\section{Framework}

Figure 1 Framework Research

Source: Adapted for research

\section{Hypotheses}

Based on the conceptual framework and the elaboration of formulation of the problem, it can be made assumptions or alleged to be verifiable, which is as follows:

a. Motivation positive and significant effect on employee performance stevedoring company PT. RMK-E Palembang

b. Incentives positive and significant effect on employee performance stevedoring company PT. RMK-E.

c. Motivation and incentive positive and significant impact on employee performance stevedoring company PT. RMK-E.

\section{METHOD}

\section{The scope of research}

The object of research is limited only to the company and its employees unloading PT RMK-E Headquarters Palembang. PT RMK-E Palembang is located at Sungai Triple Tpa 2 Palembang 30259. 


\section{Population and Sample}

This study used a sample of saturated where according Sugiyono (2017) This technique uses the entirety of the number of members of the population were used as samples for the study. Total population in this study were 68 employees, which means the sample used are all employees of unloading PT RMK-E Palembang, amounting to 68 (operational staff of 30 people, master loading 8 people, and porters 30$)$.

\section{Data and Method of Use Data types}

This study uses qualitative data which in the opinion of Sukmadinata (2013) qualitative research or qualitative research is a study used to describe a variety of phenomena, events, social activities, actions / attitudes, beliefs, perceptions, thoughts of someone either individually or in groups. In this study of qualitative data analysis that will be used is qualitative data that will be in the form of results quantified respondents made in the form of Likert scale.

\section{Data source}

Sources of data in this study are primary data. Primary data is data collected directly from the author by obtaining a subject population that is 68 respondents were collected by distributing questionnaires in the form of a statement that has been distributed to every employee writer. In the opinion of Hasan (2002) Primary data is data collected directly in the field by people doing research or concerned with statements-statements, either in the form of interviews or questionnaires.

\section{Data collection technique}

This study will use a questionnaire technique are closed, which is composed of the above statement with some answers as an option, and the respondents choose the most appropriate answer from a private individual measurement scale independent variables and the dependent variable in this study was measured by Likert scale.

\section{Data analysis technique}

Test Research Instruments

Validity test

Ghozali (2016) states an instrument said to be true if the test equipment used in obtaining research data was valid. Instrument test equipment used in this research is the validity of the construction(Construct validity). The criteria in determining the validity of an instrument is as follows:

If the value of $r$ count $>r$ table then the question is valid.

If the count $r<r$ table then the question is not valid.

The data obtained from the test results generated instrument validity memului management using the program Statistical Package for Social Science (SPSS).

The reliability test

Sugiyono (2017) which is a measure of reliability test of the level of trust in which the 


\section{International Journal of Business Management and Economic Review}

Vol. 2, No. 04; 2019

ISSN: 2581-4664

instruments were tested in the study can be used as a data collector so that it can be used repeatedly in research on the same object. This test utilizes Cronbach's Alpha method by SPSS. The same is expressed by Ghozali (2016) that while the test criteria is, if the value is greater than 0.60 Alpha (Cronbach's Alpha> 0.60), then the otherwise reliable research instruments.

\section{Classic assumption test}

Normality test

This test is done by looking at the results of the processing of the Test of normality Kolmogorov-Smirnov test through SPSS. Data is said to be normally distributed if the probability value is greater than 0.05 , but if the value of the probability otherwise then the data collected are not normally distributed or taken from a population that is not normal. (Ghozali, 2016).

\section{Test Multicollinearity}

In the opinion of Ghozali (2016) when the independent variables are interrelated causes of these variables are not mutually ontogonal. Ontogonal variable is the independent variable that the correlation between the members of the independent variables equal to zero. To detect their multikolinieritas to form hypotheses:

tolerence value $<0.10$ or $\mathrm{VIF}>10=$ happen multikolinearitas

tolerence value $>0.10$ atauu VIF $<10=$ not happen mulitikolinearitas

test heterokedastisitas

Ghozali (2016) heterocedastisity testing is used to see if the regression model occurred inequality variance of the residuals of the observations to other observations. Testing is done by looking at the graph plot between the predicted value of the dependent variable with residual value. When forming a pattern, the points spread above and below the y-axis the number 0 , then there is no heterokedastisitas. A good regression equations is when the regression equation does not happen heterocedastity.

\section{Regression Analysis}

In the opinion of Sugiyono (2017) used multiple regression analysis to predict the rise and fall of variable $\mathrm{Y}$ in one study when each or all of the variable $\mathrm{X}$ in ride lower.

$\mathrm{Y}=\alpha+\beta 1 \mathrm{X} 1+\beta 2 \mathrm{X} 2+\mathrm{e}$

Keterangan:

$\mathrm{Y}=$ Performance Officer

$\alpha=$ coefficient Constants

$\beta 1, \beta 2=$ Independent variable regression coefficient

$\mathrm{X} 1 \quad=$ Incentives

$\mathrm{X} 2$ = Motivation

$\mathrm{e}=$ The error rate or standard error

\section{Analysis Correlation Coefficient (r)}

In the opinion of Sugiyono (2017) analysis of the correlation coefficient was used to measure the relationship between variables which are closely related, if the direction and vice 
Vol. 2, No. 04; 2019

ISSN: 2581-4664

versa.

As a matter of interpretation of the correlation coefficient found is large or small, it can be guided by the following principles:

Table 3 provides Interpretation Guidelines Correlation Coefficient

\begin{tabular}{|ll|}
\hline interval coefficient & level Relationships \\
\hline 0.00 to 0.19 & Very weak \\
0.20 to 0.399 & Weak \\
0.40 to 0.599 & moderate \\
0.60 to 0.799 & Strong \\
0.80 to 1.000 & Very strong \\
\hline
\end{tabular}

Source: Sugiyono (2017)

\section{The coefficient of determination ( $\mathrm{R} 2)$}

Determinant coefficient ranged from zero up to one $(0 \leq \mathrm{R} 2 \leq 1)$. If the determination is equal to zero, then there is no influence between variable $\mathrm{X}$ to variable $\mathrm{Y}$. The results of the coefficient of determination when close to 1 then its influence is strong between the variable $\mathrm{X}$ to variable $\mathrm{Y}$, when getting closer to 0 , meaning the smaller the effect of variable $\mathrm{X}$ to $\mathrm{Y}$. (Sugiyono, 2017)

\section{Examination hypothesis}

Partial test ( $\mathrm{t}$ test)

Ghozali (2016) t test is used to see how big the influence of each independent variable $(\mathrm{X})$ to the dependent variable $(\mathrm{Y})$ significantly. The $\mathrm{t}$ test was determined by the following hypotheses:

- $\mathrm{H} 0=0$ wich one there was no correlation between each dependent variable to the independent variables.

- $\quad H A \neq 0$ wich one there is influence between each independent variable dependent variable.

- $\quad$ T table for significant value of 5\% was 0.05 and the value obtained from $\mathrm{df}=\mathrm{nk}$. $\mathrm{t}$ test results obtained by comparing the value of $t$, where $t$ is greater than $t$ table then the hypothesis is accepted.

Simultaneous Test (F)

$\mathrm{F}$ test is used to determine whether all the independent variable $(\mathrm{X})$ has the effect together or a combination of the dependent variable (Y). In the F-test, there are two ways that can be used. First through the level of significance of the test results ANOVA where if sig $<0.05$ then the hypothesis is accepted, but if it is greater then the hypothesis is rejected. The second is based on comparison of the value of $F$ arithmetic and tables. If the $F$ count $>F$ table then there is a simultaneous effect in this study, however, if the value obtained is smaller then simultaneously there is no influence between the variables X and Y. (Ghozali, 2016).

\section{RESULTS AND DISCUSSION}

\section{Research Instruments Test Results}


International Journal of Business Management and Economic Review

Vol. 2, No. 04; 2019

ISSN: 2581-4664

Validity of Test Results Research Instruments

Table 4. Results Validity Test Instruments Grain Research Variables $(\mathbf{N}=\mathbf{2 0})$

\begin{tabular}{|c|c|c|c|}
\hline \multirow[t]{10}{*}{ Incentives (X1) } & grain & r-count & Information \\
\hline & 1 & 0.659 & valid \\
\hline & 2 & .570 & valid \\
\hline & 3 & .718 & valid \\
\hline & 4 & .663 & valid \\
\hline & 5 & 0.732 & valid \\
\hline & 6 & .777 & valid \\
\hline & 7 & .777 & valid \\
\hline & 8 & 0.693 & valid \\
\hline & 9 & 0.647 & valid \\
\hline \multirow[t]{16}{*}{ Motivation (X2) } & 1 & .713 & valid \\
\hline & 2 & 0.573 & valid \\
\hline & 3 & .680 & valid \\
\hline & 4 & .639 & valid \\
\hline & 5 & .750 & valid \\
\hline & 6 & 0.802 & valid \\
\hline & 7 & 0.802 & valid \\
\hline & 8 & .788 & valid \\
\hline & 9 & .649 & valid \\
\hline & 10 & .484 & valid \\
\hline & 11 & .713 & valid \\
\hline & 12 & 0.824 & valid \\
\hline & 13 & 0.792 & valid \\
\hline & 14 & 0.525 & valid \\
\hline & 15 & .542 & valid \\
\hline & 16 & 0.707 & valid \\
\hline \multirow{13}{*}{$\begin{array}{l}\text { Performance } \\
\text { (Y) }\end{array}$} & 1 & .609 & valid \\
\hline & 2 & .671 & valid \\
\hline & 3 & 0.633 & valid \\
\hline & 4 & 0.694 & valid \\
\hline & 5 & 0.617 & valid \\
\hline & 6 & 0.635 & valid \\
\hline & 7 & .684 & valid \\
\hline & 8 & .621 & valid \\
\hline & 9 & 0.666 & valid \\
\hline & 10 & 0.679 & valid \\
\hline & 11 & .690 & valid \\
\hline & 12 & 0.699 & valid \\
\hline & 13 & 0.581 & valid \\
\hline
\end{tabular}




\section{International Journal of Business Management and Economic Review}

Vol. 2, No. 04; 2019

ISSN: $2581-4664$

\begin{tabular}{|llll|}
\hline \hline & 14 & 0.502 & valid \\
\cline { 2 - 4 } & 15 & 0.587 & valid \\
\cline { 2 - 4 } & 16 & 0.693 & valid \\
\hline
\end{tabular}

Source: Adapted from primary data

From Table 4, it is known that all the instruments item ratings (r-count)> of r-table of 0.444 , and thus the whole grain instrument is declared invalid. Referring to these results, the whole grain variables used as a research instrument qualified to serve as a measuring tool in this study.

The reliability test of Research Instruments

From table 5, it is known that all the items variable reliability test results of research shows a correlation r-count value $>0.6$. Referring to these results, the entire item variable is reliable and qualified to serve as a measuring tool in this study.

Table 5 Reliability Test Results Variable study $(\mathbf{N}=\mathbf{2 0})$

\begin{tabular}{|lllll|}
\hline No. & item & Num. of Cases & Num. of items & $\begin{array}{l}\text { Reliability } \\
\text { Test Results }\end{array}$ \\
\hline 1 & Incentives (X1) & 20 & 9 & 0.908 \\
2 & Motivation (X2) & 20 & 16 & 0.941 \\
3 & Performance (Y) & 20 & 16 & 0.927 \\
\hline
\end{tabular}

Source: processed from primary data

\section{Classic assumption test}

Normality test

Normality test results in this research look like in figure 4.1.

Figure 2 Normality Test Data

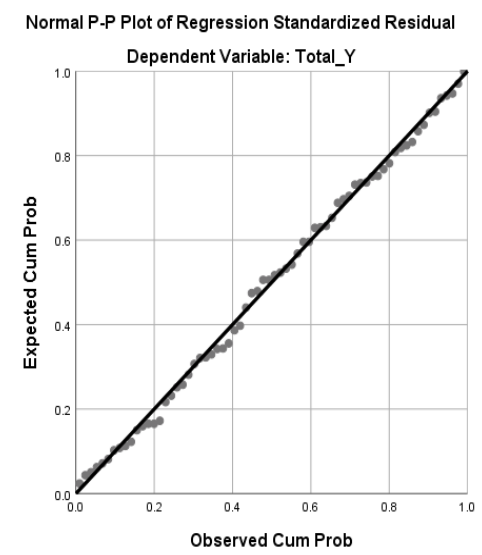

Source: processed from primary data 


\section{International Journal of Business Management and Economic Review}

Vol. 2, No. 04; 2019

ISSN: 2581-4664

From the image Figure 2 shows that the general distribution of the data shows the data moving in a linear line diagonal, where dots spread around the diagonal line and its distribution follows the diagonal line direction, so that data can be said to be normally distributed, and meet the criteria of normality. Thus the regression model can be used to predict the performance variables based on the variable of motivation and incentives.

Test Multikolineralitas

In this study multicolinearity test was used to test the regression model of the relationship between the variable incentive and motivation.

Table 6 Test Multikolinieralitas

\begin{tabular}{|llll|}
\hline No. & Independent variables & \multicolumn{2}{l|}{ collinearity Statistics } \\
\cline { 3 - 4 } & & tolerance & VIF \\
\hline 1 & Incentives (X1) & .487 & 2,055 \\
2 & Motivation (X2) & .487 & 2,055 \\
\hline
\end{tabular}

Source: processed from primary data

From Table 6 shows that the value of tolerance to both independent variables $>0.10$, and VIF < of 10.00, which means that in this study there are no issues multikolineralitas.

Test Heteroskidastity

Heteroskidastity test aims to test whether the regression model occurred inequality residual variance from one observation to another observation. Heteroscedasticity test results of this research look like in figure 3 below.

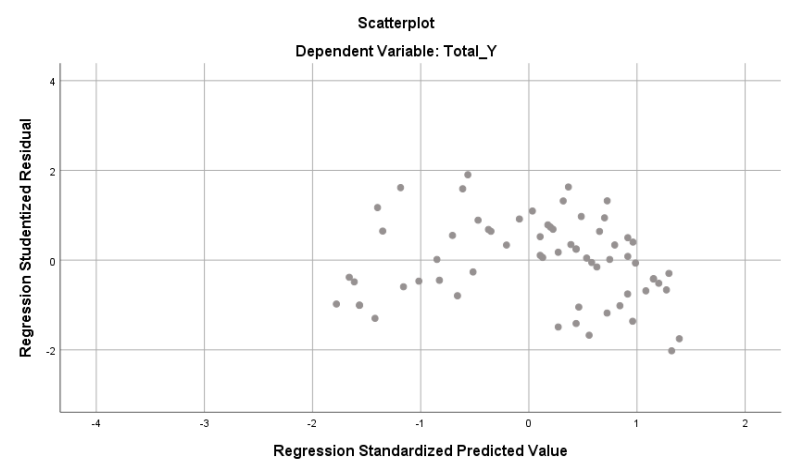

Source: processed from primary data

Figure 3 Test Heteroskidastity scatterplot

Based on Figure 3, the test results from the diagram scatterplot shows the data of the dots does not form a specific pattern and spread evenly both above and below the zero line, not gather at one point, sehinnga in this study there is no inequality of the variance of the residuals of the another observation to observation (heterokedastisitas). 
Vol. 2, No. 04; 2019

ISSN: 2581-4664

\section{Multiple Linear Regression Analysis}

In this research, there are more than one independent variable that will be tested in order to determine the influence that exists between Incentives and Motivation Working together the Employee Performance then performed multiple regression analysis.

Table 7 Coefficient SPSS Regression

\begin{tabular}{|c|c|c|c|c|c|}
\hline \multirow{2}{*}{ Model } & \multicolumn{2}{|c|}{ Coefficients unstandardized } & \multirow{2}{*}{$\begin{array}{l}\text { standardized } \\
\text { Coefficients } \\
\text { beta }\end{array}$} & \multirow[t]{2}{*}{$\mathrm{T}$} & \multirow[t]{2}{*}{ Sig. } \\
\hline & $\mathrm{B}$ & Std. Error & & & \\
\hline (Constant) & 18049 & 2,840 & & 6356 & 0000 \\
\hline$1 \longdiv { \text { Incentive } }$ & 0240 & 0105 & 0177 & 2,291 & 0025 \\
\hline Motivation & 0596 & 0060 & 0766 & 9947 & 0000 \\
\hline
\end{tabular}

Source: Results of data processed SPSS 24.0, 2018

Based on table 4.8, the regression equation can be formed as follows: Performance $(\mathrm{Y})=$ $18.049+0.240 \mathrm{X} 1+0.596 \mathrm{X} 2$

Of the value equation regression estimation function looks a value of 18.049. It is clear that without the influence of the independent variable incentive and motivation, then the performance of employees of stevedoring company PT. RMK- E is equal to 18.049.

Incentives variable coefficient value of 0.240 which explains that any changes to the incentives, performance will be unchanged at 0.240 assuming other variables are Motivation, in other words that the higher the incentive the higher the employee's performance stevedoring company PT. RMK- E Palembang.

Regression coefficients represent variable Motivation obtained a positive value of 0.596 which explained that any change in motivation, the performance is directly proportional amounted to 0.596 assuming other independent variables are incentives, in other words that the higher the motivation, the higher the performance of employees of the Company unloading PT. RMK- E Palembang.

\section{Analysis Correlation Coefficient (R) and determination (R2)}

In this study, the correlation coefficient analysis is used in order to know how much / tight relationship between independent variables (insenteif and motivation) and the dependent variable (performance). The magnitude of the relationship between these variables are shown in Table 8 below.

Table 8 Correlation and Determination 


\section{International Journal of Business Management and Economic Review}

Vol. 2, No. 04; 2019

ISSN: 2581-4664

\begin{tabular}{|lllll|}
\hline \hline Model Summaryb & & & \\
\hline Model & R & R Square & $\begin{array}{l}\text { Adjusted } \\
\text { Square }\end{array}$ & R Std. Error of the Estimate \\
\hline 1 & $0.901 \mathrm{a}$ & 0812 & 0807 & 2,444 \\
\hline
\end{tabular}

Source: Results of data processed SPSS 24.0, 2018

In Table 8 obtained coefficient $(\mathrm{R})$ is a positive sign which is 0.901 for Incentive and Motivation, these results may indicate there is a close relationship between the incentive, motivation and performance because it is above 0.5 .

The coefficient of determination (R2) Incentives and Motivation in Table 8 by 0,812 or $81.2 \%$, which means the incentive and motivation may explain the variable employee performance amounted to $81.2 \%$, while $18.8 \%$ is explained by other variables not measured in this study,

The relationship between the variable incentive and motivation with employee performance variables in this study are very strong, variable incentive and motivation has been able to provide the required information in predicting employee performance variables.

\section{Hypothesis testing}

Simultaneously Test (Test F)

To determine whether the independent variables jointly significant effect on the dependent variable used $\mathrm{F}$ test following $\mathrm{F}$ test to see who can be seen from Table 9.

Table 9 Results of ANOVA / Test Concurrent / test F

\begin{tabular}{|c|c|c|c|c|c|c|}
\hline \multicolumn{7}{|c|}{ ANOVAa } \\
\hline Model & \begin{tabular}{|l} 
Sum \\
Squares
\end{tabular} & \begin{tabular}{l|l} 
of & Df \\
\end{tabular} & \begin{tabular}{|l|} 
mean \\
Square
\end{tabular} & $\bar{F}$ & Sig. & \\
\hline \multirow[t]{2}{*}{1} & $\begin{array}{l}\text { Regression } \\
\text { residual }\end{array}$ & $\begin{array}{l}1679.584 \\
388.107\end{array}$ & \begin{tabular}{|l|}
2 \\
65
\end{tabular} & $\begin{array}{l}839.792 \\
5.971\end{array}$ & 140.648 & \multirow[t]{2}{*}{, $000 \mathrm{~b}$} \\
\hline & Total & 2067.691 & 67 & & & \\
\hline
\end{tabular}

Based on the obtained value 0,000 Table 9 where the value is $<0.05$. As for the value of $F$ count obtained 140.648 . With a confidence level of $95 \%$ or with the value of $\alpha=5 \%$ and by using the degrees of freedom df (degree of freedom) obtained Ftabel to 68 respondents is 3.05. In order to get the comparison value F-Count and F-table, 140.648> 3.05, which means there is a significant effect of incentives variable (X1) and motivation (X2) on Performance (Y). Significant value based on calculations, 0,000 less than alpha 0.05 (Sig F $=0.000<\alpha 0.005$ ). From these values it can be concluded that the independent variables are the incentive and motivation together influential significantly on employee performance.

Partial test (t test)

Partial test ( $t$ test) was used to test the significance of the coefficient of each independent variable, whether Incentive (X1), and Motivation (X2) actually partial effect (separately) on the 


\section{International Journal of Business Management and Economic Review}

Vol. 2, No. 04; 2019

ISSN: $2581-4664$

dependent variable is the performance of employees in stevedoring company PT. RMK-E Palembang. The results of the partial test or $t$ test using SPSS program are as follows:

Table 10 Regression Analysis t test

\begin{tabular}{|c|c|c|c|c|c|c|}
\hline \multicolumn{5}{|c|}{ Coefficientsa } & & \\
\hline \multirow[t]{2}{*}{ Model } & $\begin{array}{l}\text { Coefficien } \\
\text { ts } \\
\text { unstandar } \\
\text { dized }\end{array}$ & $\begin{array}{l}\text { standardiz } \\
\text { ed } \\
\text { Coefficien } \\
\text { ts }\end{array}$ & $\mathrm{T}$ & \multirow[t]{2}{*}{ Sig. } & & \\
\hline & $\mathrm{B}$ & Std. Error & beta & & & \\
\hline \multirow{3}{*}{1} & (Constant) & 18.049 & 2,840 & & 6,356 &, 000 \\
\hline & Incentive &, 240 &, 105 &, 177 & 2,291 & .025 \\
\hline & $\begin{array}{l}\text { Motivatio } \\
\mathrm{n}\end{array}$ & $\overline{, 596}$ & .060 &, 766 & 9.947 & $\overline{, 000}$ \\
\hline
\end{tabular}

a. Depende Variable: Total

Employee Performance

Based on the information table 10 to do the analysis:

1. Testing The first hypothesis (H1), comparing the value of $t$ arithmetic and $t$ table variable incentive of 2.291> 1.995. Then the significance of $0.025<0.05$. So the researchers conclude that $\mathrm{H} 1$ is accepted, it means that the variable incentives (X1) there is an influence on the performance variable (Y).

2. Testing the second hypothesis (H2), comparing the value of $\mathrm{t}$ arithmetic and $\mathrm{t}$ table work motivation variable of 9.947> 1.995. Then the significance of $0.000<0.05$. So the researchers conclude $\mathrm{H} 2$ is accepted, it means that the motivation variable (X2) there is an influence on the performance variable (Y).

In Table 10 it can be seen that the value of the variable $\beta$ Incentive (X1) is 0.240 and the motivation variable (X2) is 0.596 . Independent variables that have a value that is away from the value $\beta 0$ is a variable that closely affect the dependent variable. Variable Motivation (X2) has a value $\beta$ larger and further away from a value of 0 , it can be concluded that the motivation dominant influence on employee performance.

\section{DISCUSSION}

Influence of Variable Incentives on Employee Performance PT Stevedoring Company. RMK-E Palembang

The incentive is in addition to the remuneration granted to certain employees whose performance over standard achievement. Variable Incentive positive results and significant impact on employee performance Empirical facts showed that that includes bonuses, commissions, and awards have a positive and significant impact on employee performance stevedoring company PT. RMK-E Palembang (Y) which means that the first hypothesis (H1) is accepted. This fact is in line with research conducted by Lia Mayang Sari (2013), which states that bonuses, commissions and profit sharing affect the performance of employees in the company. The results of this study indicate incentives make employees do better in completing the work within the time that has been set. Incentives are given correctly and match the 


\section{International Journal of Business Management and Economic Review}

Vol. 2, No. 04; 2019

ISSN: 2581-4664

percentage of jobs to encourage employees to improve their performance through training or seminars, both held company and outside the company. It is expected to support career and develop their potential so that the work can be done more effectively and efficiently. In addition, the company expects to achieve the purposes and benefits as well as the existence without having a lot of obstacles.

Influence of Variable Motivation on Employee Performance PT Stevedoring Company. RMK-E Palembang

Based on the test results obtained by regression and the first hypothesis that motivation variables significantly influence employee performance stevedoring company PT. RMK- E Palembang. This is supported by several theories. According to Gibson (2012), there are several factors summarized in three of the most dominant variable in influencing behavior and employee performance, including:

- The variables contained within an individual in the form of skill, mental and physical, family background and expertise and demographics.

- Variables include the organization of resources, leadership, organizational structure and job design.

- Psychological variables, namely, knowledge, behavior, personality, and others.

Mangkunagara (2006) points out the two factors that affect the performance of that internal factors are factors that discusses the nature of the individual and the external factors are factors that increase or decrease in performance based environmental origin.

The description of the respondents know the percentage score responder for motivation variable is $79 \%$, which means that the motivation of employees unloading PT RMK-E Palembang is good enough. This suggests that motivation is needed by employees unloading PT RMK- E Palembang. According to Smith and Wakeley, that one is encouraged to move because he hoped that it would bring the state more satisfying than the current situation.

Variable Motivation Has The Most Dominant Influence Employee Performance Against PT Stevedoring Company. RMK-E Palembang

Based on the test results of research that has been done shows that more dominant than the motivation variable incentive variables on the performance Stevedoring Company Employees PT. RMK-E Palembang, which is supported by theory David McClelland argued about a person's desire to achieve high performance in which the motivation variable in the study had a very important influence in determining the success of employees. Employees who have a good achievement motivation have high morale so that the goal of achieving the performance not only rewards but employee satisfaction.

\section{CONCLUSIONS AND RECOMMENDATIONS}

\section{Conclusion}

Based on the results of research and discussion that has been done in the previous chapter, it can be concluded empirically that:

1. Motivation positive and significant effect on employee performance stevedoring company PT. RMKE Palembang. If the positive work motivation, then the resulting performance increase. Conversely, if the motivation to work less, then the performance of the resulting decreases. 


\section{International Journal of Business Management and Economic Review}

Vol. 2, No. 04; 2019

ISSN: 2581-4664

2. Incentives have a positive and significant impact on employee performance stevedoring company PT. RMK-E Palembang. If employees obtain an adequate intensive employee performance can be further improved.

3. Motivation and Incentives simultaneously have a positive and significant impact on employee performance stevedoring company PT. RMK-E Palembang. Intensive, motivation, mutual influence on employee performance, providing appropriate incentives to employees resulted in the employee's performance does not match the target.

4. Variable work motivation is the dominant influence on employees of stevedoring company PT. RMK-E Palembang.

\section{SUGGESTION}

From the conclusions that have been obtained in the study "INCENTIVES AND MOTIVATION EFFECT ON THE PERFORMANCE OF EMPLOYEES IN PART STEVEDORE PT. RMK ENERGY PALEMBANG ", the researchers gave the following advice.

a. Employees should further improve performance so that the company can provide the appropriate incentives to work.

b. Stevedoring company PT. RMK-E Palembang need to schedule a discussion on the problems that occur in the company to motivate employees so as to create employee performance improvement.

c. Employees must have a special motivation in him in accordance with the company's goals. That's because, with the motivation to work will improve its performance.

d. The good performance of each employee is required to obtain results that correspond to the bonus will be paid by the company.

e. Companies should further clarify the details of incentives so that employees can earn bonuses depending on their performance.

f. Comfortable working environment is needed employees to have the selfmotivation and gain increased incentives so as to create a good performance

g. To improve performance, should pay attention to intensive leadership and motivation in order to produce a satisfactory performance.

\section{REFERENCES}

A.F.Stoner, Jame, 2017. Manajemen, Jakarta: PT.Prenhallindo

Agus, Dharma, 2014. Manajemen Supervisi. Jakarta : Raja Grafindo Persada

Alex S. Nitisemito, 2014, Manajemen Personalia, Edisi kedua, Ghalia Indonesia.

Algifari, 2010. Analisis Regresi Teori, Kasus dan Solusi, Edisi Pertama, Universitas Gajah Mada, Yogyakarta : BPFE.

Ali Zainuddin, 2013. Metode Penelitian Hukum. Sinar Grafika. Jakarta 


\section{International Journal of Business Management and Economic Review}

Vol. 2, No. 04; 2019

ISSN: 2581-4664

Alwi, Syafaruddin, 2011. Manajemen $\quad$ Sumber Daya Manusia $\quad$ Strategi Keunggulan. Kompetitif, BPFE; Yogyakarta.

Anwar Parabu Mangkunegara, 2015. Manajemen Sumber Daya Manusia Perusahaan, PT. Remaja Rosda Karya: Bandung.

Anwar Prabu Mangkunegara, 2015. Manajemen Sumber Daya Manusia Perusahaan, Cetakan Kedelapan. Bandung: PT Remaja Rosdakarya.

Arep dan Tanjung. 2012. Manajemen Motivasi. Jakarta : PT. Grasindo

Arep, Ishak dan Hendri Tanjung. 2003. Manajemen Sumber Daya Manusia. Jakarta : Universitas Trisakti

Arikunto, Suharsimi. 2006. Prosedur Penelitian Suatu Pendekatan Praktik. Jakarta : Rineka Cipta

Aritonang, 2010. Perilaku Organisasi, Cetakan Ketiga, CV. Citra Media, Surabaya.

Bambang, Wahyudi. 2012. Manajemen Sumber Daya Manusia. Bandung: Sulita

Cheng and Kalleberg,1996, Personalia Management (terjemahan), John Willey dan Sons,Ny, Daan Suganda, Sinar Baru, Bandung

Davis, Keith dan Newstrom, 2004. Perilaku Dalam Organisasi. Edisi Ketujuh. Penerbit Erlangga, Jakarta

Dessler, Gary. 2015. Manajemen Sumber Daya Manusia. Jakarta : Index

Dubrin, 2015. Leadership (Terjemahan), Edisi Kedua, Jakarta : Prenada Media.

Friska, 2004. Kepemimpinan dalam Organisasi, Fakultas Ekonomi Universitas Sumatera Utara.

Gibson, Ivancevich dan Donelly. 2012. Organisasi. Edisi Kedelapan, Jilid 2. Binarupa Aksara, Jakarta

Gitosudarmo, I dan I Nyoman Sudita. 2014. Perilaku Keorganisasian. Yogyakarta : BPFE

Gomes, Faustino Cardoso. 2005. Manajemen Sumber Daya Manusia. Yogyakarta : Penerbit Andi

Hani, Handoko, 2008. Manajemen Personalia dan Sumber Daya Manusia. UGM, Yogyakarta: BPFE. 


\section{International Journal of Business Management and Economic Review}

Vol. 2, No. 04; 2019

ISSN: 2581-4664

Hasibuan, Malayu, SP, 2017, Partisipasi, Tarsito, Bandung.

Hasibuan, Malayu. 2013. Manajemen Sumber Daya Manusia. Cetakan Kesembilan. Jakarta : PT. Bumi Aksara

Imam, Ghozali, 2016. SPSS dan Analisis Multivariate, Semarang: Fakultas Ekonomi Universitas Diponegoro.

Istianto, Bambang. 2009. Manajemen Pemerintahan dalam Perspektif Pelayanan Publik. Jakarta : Mitra Wacana Media

Kreitner dan Kinicki, 2013. Perilaku Organisasi. Jakarta : Salemba Empat

Laswiyati, 2005. Jurnal Pendidikan. Dalam Http://ml.scribd.com/doc/jurnal-pendidikan.

Luthans, Fred, 2006, Organizational Behavior, 5th edition,Singapore McGraw-Hill, International Edition

Luthan, F, 2005, Organizational Behavior, The McGraw-Hill Coompanies, Inc.

Manullang, M. 2015. Dasar-dasar Manajemen. Yogyakarta : Gadjah Mada University Press

Mathis dan Jackson, 2012. Manajemen sumber daya manusia, Jakarta : Salemba Empat.

Nawawi, Hadari. 2011. Manajemen Sumber Daya Manusia. Jakarta : Ghalia Indonesia

Nitisemito, S Alex. 2014. Manajemen Personalia. Graha Indonesia. Jakarta

Ranupandojo, Heidjrachman. 2004. Manajemen Sumber Daya Manusia. Jakarta : Universitas Terbuka

Robbins SP, dan Judge. 2014. Perilaku Organisasi. Jakarta : Salemba Empat

Robbins, 2003. Essentials of Organizational Behavior (Terjemahan), Edisi Kelima, Penerbit Erlangga, Jakarta.

Sarwoto, 1991. Dasar-dasar Organisasi dan Manajemen. Jakarta : Ghalia Indonesia

Sarwoto,2000, Dasar-Dasar Organisasi Management, Ghalia Indonesia,Jakarta

Siagian, Sondang. 2010. Organisasi Kepemimpinan dan Perilaku Administrasi. Jakarta: PT. Gunung Agung.

Simamora, Henry. 2012. Manajemen Sumber Daya Manusia. Jakarta : PT. Gramedia Pustaka 


\section{International Journal of Business Management and Economic Review}

Vol. 2, No. 04; 2019

ISSN: 2581-4664

\section{Utama}

Siswanto, B. Sastrohadiwiryo. 2010. Manajemen Tenaga Kerja Indonesia. Edisi 2. Jakarta : PT. Bumi Aksara

Slamet, 2007. Kiat Meningkatkan Kinerja, Cetakan Pertama. Jakarta : PT. Rineka Cipta.

Sopiah. 2011. Perilaku Organisasional. Malang : ANDI.

Sugiyono, 2012. Metode Penelitian Bisnis. Bandung: Alfabeta.

Sugiyono, 2006. Metode Penelitian Administrasi. Bandung : Alfabeta

Sugiyono, 2017. Statistika Untuk Penelitian, Cetakan Ketiga, Bandung: Alfabeta.

Stonner, James, A.F. 1996. Manajemen. Edisi II. Prenhalindo. Jakarta

Sukmadinata, Syaodih Nana. 2013. Metode Penelitian Pendidikan. Bandung: Remaja Rosdakarya

Supardi, 2012. Penelitian Tindakan Kelas. Jakarta : Bumi Aksara

Sutrisno, Hadi. 2014. Metodologi Research. Yogyakarta : Yayasan Penerbit Fakultas

Sutrisno, Hadi, 2015. Metodelogi Penelitian Bisnis, Alfabeta Bandung.

Tika, Pabundu. 2014. Budaya Organisasi dan Peningkatan Kinerja Perusahaan. Jakarta : Bumi Aksara

Umar, H. 2003. Evaluasi Kinerja Perusahaan. Jakarta : Gramedia Pustaka Utama

Veithzal, Rivai. 2015. Manajemen Sumber Daya Manusia. Jakarta : Raja Grafindo Persada

Veithzal Rivai, 2015, Manajemen Sumber Daya Manusia untuk Perusahaan, PT. Remaja Rosda Karya ; Bandung

Wahyudin dan Prasetyo, E. 2006. Perencanaan Pendidikan Partisipatori. Jakarta : Rineka Cipta

Winardi, 2014. Teori Organisasi dan Pengorganisasian. Divisi Buku Perguruan Tinggi

Wursanto, IG. 2002. Manajemen Kepegawaian. Yogyakarta : Penerbit Kanisius 